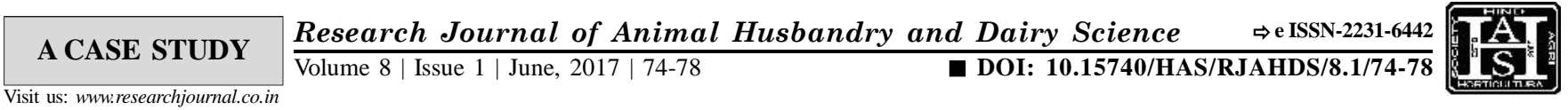

\title{
Economics of quail farming
}

\author{
R. SATHIYA, C. PAZHANISAMY AND V. BANUMATHY
}

\begin{abstract}
An attempt has been made to study the economics of quail farming. The present study revealed that the total cost of Rs. 34.39 was incurred in the production of a bird. The net return per bird was Rs. 0.61 and per batch was Rs.1525. Break - even point was identified and it was 2278 birds per batch. The farm was maintaining 2500 birds per batch which was greater than break even quantity. The producer'sprice was Rs.28.85 per bird and Rs.72, 125 per batch. The cost incurred by retailer per bird was Rs. 4.6 and Rs. 11,500 per batch;of which, transport cost was the major component. It could be revealed that the producer share in consumer's rupee was 64 per cent. The marketing cost and marketing margin altogether occupied 36 per cent in consumer's rupee. In quail farming, cost of feed, inadequate credit and getting license were the major problem. By overcoming these problems through government support in terms of providing financial, market facilities and extension services, quail farmers can run the business in a profitable way thereby there is a vast potential for reducing protein deficiency and creating employment opportunities for young people.
\end{abstract}

KEY WORDS : Quail farming, Cost of production, Break event point, Marketing cost, Margin, Price spread

HOW TO CITE THIS PAPER : Sathiya, R., Pazhanisamy, C. and Banumathy, V. (2017). Economics of quail farming, India. Res. J. Animal Hus. \& Dairy Sci., 8(1) : 74-78 : DOI: 10.15740/HAS/RJAHDS/8.1/74-78.

Address for correspondence :

R. Sathiya, Department of Agricultural Economics, Annamalai University, CHIDAMBARAM (T.N.) INDIA

Email : rameshsathiya24@gmail.com

Associated Authors' :

C. Pazhanisamy and V. Banumathy, Department of Agricultural Economics, Annamalai University, CHIDAMBARAM (T.N.) INDIA 